\title{
FC36-96G010148
}

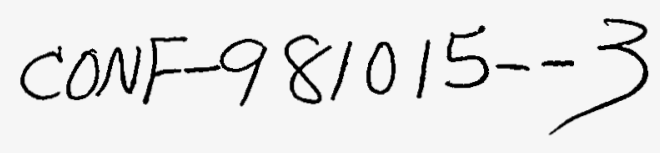

\section{INDIRECTLY HEATED FLUIDIZED BED BIOMASS GASIFICATION USING A LATENT HEAT BALLAST}

\author{
R. Pletka, R. Brown, and J. Smeenk \\ Center for Coal and the Environment \\ Iowa State University \\ 286 Metals Development Building \\ Ames, IA 50011 USA
}

\begin{abstract}
The objective of this study is to improve the heating value of gas produced during gasification of biomass fuels using an indirectly heated gasifier based on latent heat ballasting. The latent heat ballast consists of lithium fluoride salt encased in tubes suspended in the reactor. The lithium fluoride has a melting point that is near the desired gasification temperature. With the ballast a single reactor operating in a cyclic mode stores energy during a combustion phase and releases it during a pyrolysis phase. Tests were carried out in a fluidized bed reactor to evaluate the concept. The time to cool the reactor during the pyrolysis phase from $1172 \mathrm{~K}\left(1650^{\circ} \mathrm{F}\right)$ to $922 \mathrm{~K}\left(1200^{\circ} \mathrm{F}\right)$ increased $102 \%$ by use of the ballast system. This extended pyrolysis time allowed $33 \%$ more biomass to be gasified during a cycle. Additionally, the total fuel fraction pyrolyzed to produce useful gas increased from $74 \%$ to $80 \%$. Higher heating values of 14.2 to 16.6 $\mathrm{MJ} / \mathrm{Nm}^{3}$ (382-445 Btu/scf) on a dry basis were obtained from the ballasted gasifier.
\end{abstract}

Keywords: pyrolysis, ballast, indirectly heated reactor, fluidized bed

\section{INTRODUCTION}

The objective of this research was to develop a pyrolytic gasifier that produces a gas of higher energy content than typically produced during biomass gasification. Higher energy densities in the product gas are achieved by indirectly heating the gasifier using a latent heat ballast.

Gas produced in an air-blown biomass gasifiers typically have heating values only 10 to $20 \%$ that of natural gas. This low heating is largely the result of nitrogen diluting the producer gas. Oxygen could be used as the fluidization agent but high capital costs preclude this from consideration at the relatively small sizes envisioned for most biomass energy systems. In principle, the heat generated by partial combustion of the biomass can be replaced with another heat source. If this is done, air is not required and most of 


\section{DISCLAIMER}

This report was prepared as an account of work sponsored by an agency of the United States Government Neither the Unired States Governmear nor any agency thereof, nor any of their employees, makes any werranty, express of implied, or assumes any legal liability or responsibility for the zecuracy, completeness, or usefulness of any information, apparatus, product, or process diselosed. or represents that its use would not infringe privately owned rights. Referesce berein to any speciric commercini product, process, or service by trade name, traderrart, inanufacturer, or otherwise does not aecessarily constitute or imply its endorsemeat. recommendation, or favoring by the United States Governmeas or any ageacy thereof. The views and opinions of authors expressed herein do not necsearily state or reflect those of the United States Governmeat or any agency thereof. 


\section{DISCLAIMER}

Portions of this document may be illegible in electronic image products. Images are produced from the best available original document. 
the nitrogen can be removed from the producer gas resulting in an increased heating value. Several methods have been devised for moving heat into the gasifier. These methods include transferring hot solids from the combustor to the pyrolyzer (Battelle, 1985), transferring a chemically regenerable heat carrier between these two reactors (Dallas et al., 1986), and transferring heat through a wall common to the reactors (Mansour, et al., 1995).

A simpler and potentially less costly indirectly heated gasifier has been developed at Iowa State University (Stobbe et al., 1996). The gasifier consists of a fluidized bed reactor containing a thermal ballasting system based on high temperature phase change material (PCM). A reactor operating in a cyclic mode transfers heat from burning biomass to the ballast during a combustion phase. This stored heat is then released during a pyrolysis phase to generate a medium enthalpy gas from biomass. Thus, by temporally rather than spatially separating combustion and pyrolysis, indirectly heated gasification can be accomplished in a single reactor.

\section{RESEARCH EQUIPMENT AND METHODS}

An integral part of this study is the equipment and methods used to perform the tests. A pilot-scale fluidized bed biomass gasifier located at Iowa State University was operated with and without the latent heat ballast to generate the data needed for this study. This equipment and its operation are discussed in this section.

\section{Pilot Plant Setup}

A pilot-scale fluidized bed reactor was used to perform the experiments. Figure 1 is a schematic of the pilot plant. The system is rated at $800 \mathrm{~kW}(2.75 \mathrm{MMBtu} / \mathrm{hr})$ thermal input which corresponds to an average throughput of $180 \mathrm{~kg} / \mathrm{hr}(400 \mathrm{lb} / \mathrm{hr})$ of solid biomass fuel at a heating value of $2.3 \mathrm{~kJ} / \mathrm{kg}$ (7000 BTU/lb). The major components of the plant include the fluidized bed reactor, the fluidization gas system, the fuel delivery system, the data acquisition system, and the gas sampling system.

The fuel is processed in an atmospheric bubbling fluidized bed reactor. Because fluidized beds can handle a large variety of feedstocks, they are well suited for this application. The reactor is $46 \mathrm{~cm}$ (18 in) in diameter and measures $2.44 \mathrm{~m}(8 \mathrm{ft})$ tall. The reactor wall is lined with refractory for protection and insulation.

The bed can be fluidized with either air or steam. Air, used for reactor heat up and the combustion phase of the ballasted gasification cycle, can be preheated to $870 \mathrm{~K}$ (1100 $\left.{ }^{\circ} \mathrm{F}\right)$. Superheated steam, at flow rates up to $113 \mathrm{~kg} / \mathrm{hr}(250 \mathrm{lb} / \mathrm{hr})$ and temperatures approaching $870 \mathrm{~K}\left(1100^{\circ} \mathrm{F}\right)$, is used to fluidize the bed during the pyrolysis phase of the cycle. The particulate-laden producer gas exits the reactor through the freeboard and passes through a series of cyclones. Upon leaving the final cyclone, the combustible gas is ignited electrically to form a flare. 


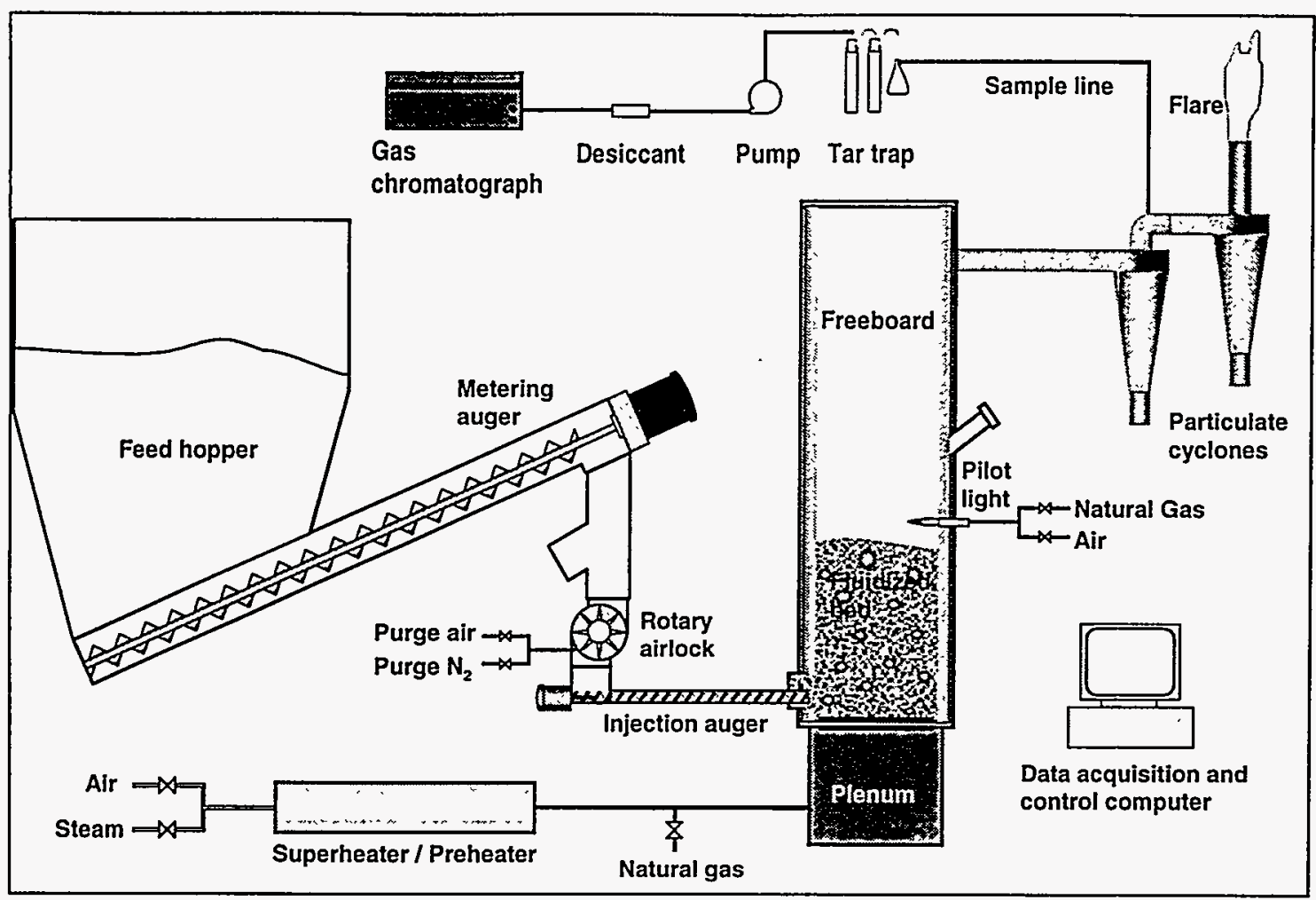

Figure 1. Schematic of the Pilot Plant.

Waste seed corn was used as the fuel for all the experiments in this study. A variable speed auger meters the fuel into a $0.31 \mathrm{~m}$ (12 in) rotary airlock where it falls into a constant-speed injection auger. The high-speed auger injects the fuel into the bottom of the fluidized bed. A small amount of purge gas is supplied below the airlock to prevent backflow of producer gas. Temperatures, pressures, and flows are monitored throughout the process by a data acquisition system. In particular, nine thermocouples are immersed in the fluidized bed to measure its temperature and to evaluate the degree of bed mixing. Poorly mixed beds may lead to hot spots and bed agglomeration.

Gas produced is sampled using a gas chromatograph (GC) and a Fourier transform infrared spectrometer (FT-IR). The gas sample is pulled from the exhaust stream immediately following the first cyclone. A combination of water trap, two condensing impingers, and Drierite desiccant removes tar, moisture, and particulates from the gas before it passes through the analytical instruments.

\section{Latent Heat Ballast Design}

The latent heat ballast is immersed in the fluidized bed. Its purpose is to intermittently store heat released during combustion and release it during the pyrolysis phase of the cyclic process. The PCM selected for the ballast is lithium fluoride (LiF). LiF has a very high latent heat of fusion $(1050 \mathrm{~kJ} / \mathrm{kg})$ and its melting point of $1121 \mathrm{~K}\left(1558^{\circ} \mathrm{F}\right)$ is compatiable with the combustion and pyrolysis phases of the gasification cycle. 
The LiF is contained in a collection of stainless steel ballast tubes. Each tube is $25.4 \mathrm{~mm}$ ( $1 \mathrm{in}$ ) in diameter and $610 \mathrm{~mm}$ ( $24 \mathrm{in}$ ) long. Each of the ballast tubes is filled with $0.3 \mathrm{~kg}$ $(0.66 \mathrm{lb})$ of $\mathrm{LiF}$. An air pocket left in the tubes allows for expansion of the LiF. Fortyeight ballast tubes, covering about $15 \%$ of the bed cross sectional area, have a total latent heat storage capacity of $15,100 \mathrm{~kJ}$.

The ballast tubes are supported from the bottom of the reactor as shown in Figure 2. A layer of ceramic balls placed on top of the distributor plate protects the plate from heat transfer from the tubes and improves gas distribution. The honeycomb support structure allows tube placement throughout the bed.

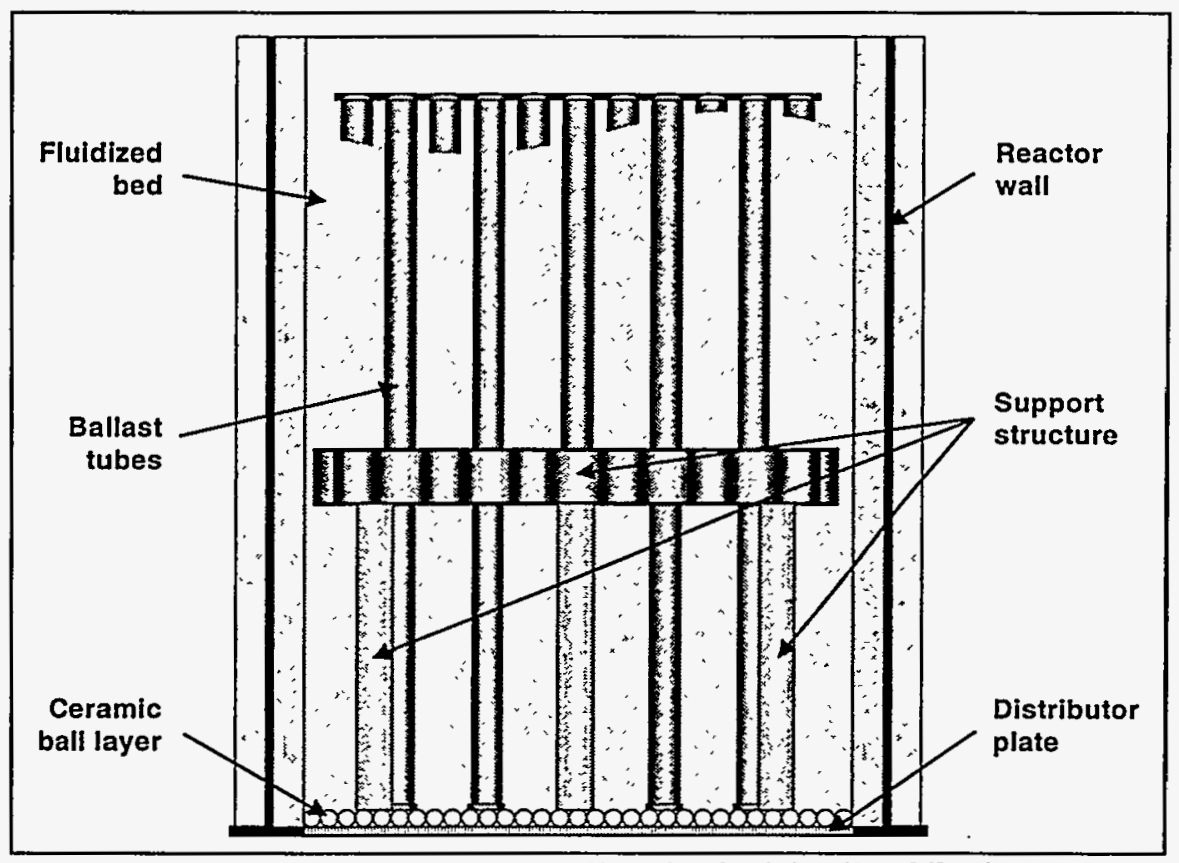

Figure 2. Latent Heat Ballast in the Fluidized Bed.

\section{Experimental Procedures}

Similar procedures are followed for ballasted and unballasted gasification tests. During the combustion phase, biomass fuel is fed into the bed at a rate of $45.4 \mathrm{~kg} / \mathrm{hr}(100 \mathrm{lb} / \mathrm{hr})$. Biomass combustion brings the bed temperature above $1172 \mathrm{~K}\left(1650^{\circ} \mathrm{F}\right)$ to ensure that the PCM melts. To begin pyrolysis, the air flow is secured and the steam flow and fuel feed rates are set. A constant superficial steam flow velocity was used in order to keep heat transfer conditions similar between the ballasted and unballasted experiments. For unballasted tests, in which the only heat capacity of the reactor comes from the fluidizing media (sand) and the ceramic walls, the mass flow rate of steam is approximately 107 $\mathrm{kg} / \mathrm{hr}(235 \mathrm{lb} / \mathrm{hr})$. For ballasted tests steam flow rate is reduced to $90.3 \mathrm{~kg} / \mathrm{hr}(206 \mathrm{lb} / \mathrm{hr})$. For all tests, superheated steam is injected into the reactor at $790 \mathrm{~K}\left(960^{\circ} \mathrm{F}\right)$. The fuel feed rate is adjusted to give the desired steam-fuel ratio. The reactor temperature is allowed to decrease (due to the endothermic reactions) to approximately $922 \mathrm{~K}\left(1200^{\circ} \mathrm{F}\right.$ ) at which time the cycle is repeated. 


\section{RESULTS AND DISCUSSION}

Over 60 tests were performed with and without the ballast to characterize the performance of the reactor. The ballast was operated at high temperature for approximately 35 hours. An additional 15 hours were spent doing baseline tests. The effect of the ballast on reactor cooling time and the average producer gas composition was examined.

\section{Reactor cooling time}

Thermal mass is essential to the successful operation of a pyrolysis reactor. The purpose for adding thermal mass is to allow more fuel to be processed. Reactor cooling time is an important means of characterizing the thermal behavior of the system. By adding thermal mass to the system, the latent heat ballast should significantly increase the amount of time it takes for the reactor to cool. Cooling time results are presented first for nonreactive conditions (i.e. steam but no fuel injected into hot bed) and reactive conditons (i.e., steam and fuel injected into hot bed).

Three different tests are used to observe the effect of the latent ballast on the cooling curves for the reactor during steam injection with no. The purpose of the first test is to obtain cooling curves for the reactor with no latent ballast in the reactor. The second test provides cooling curves with 48 latent heat ballast tubes in the reactor and a starting bed temperature $\left(1117 \mathrm{~K}, 1550^{\circ} \mathrm{F}\right)$ below the melting point of the $\operatorname{LiF}\left(1121 \mathrm{~K}, 1558^{\circ} \mathrm{F}\right)$. This test is reported so that the effect of sensible heat from the ballast system can be compared to the latent heat effect of the PCM. The third test also uses 48 tubes in the reactor but starts with a bed temperature $\left(1183 \mathrm{~K}, 1670^{\circ} \mathrm{F}\right)$ above the melting point of the $\mathrm{LiF}$; thus, the latent heat of the ballast tubes contributes to the cooling curves. The test results are shown in Figure 3.

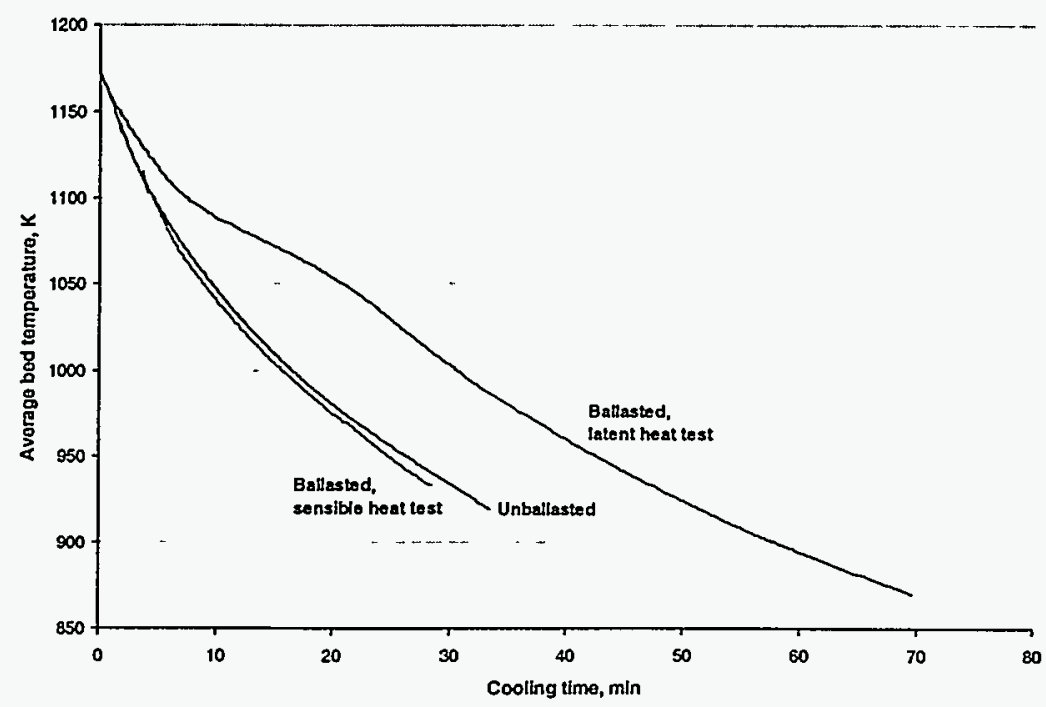

Figure 3. Reactor Cooling Curves (Steam Only) 
The cooling curves for the reactor operating with no phase change material and the reactor operating with phase change material starting below the melting point of the material are essentially the same, about 33 minutes. On the other hand, when the phase change material starts above the melting point, inflections appear in the cooling curve corresponding to the release of heat from the solidifying phase change material. The time required for the reactor to cool to $922 \mathrm{~K}$ in this instance increases from 33 to 51.2 minutes, an increase of $55 \%$. Clearly, this increase is due to the latent heat of fusion and not the sensible heat of the $\mathrm{LiF}$.

To observe the effect of the latent heat ballast during pyrolysis of biomass, four different fuel flow rates (and thus four steam-fuel ratios) at $91,113,136$, and $159 \mathrm{~kg} / \mathrm{hr}(200,250$, $300,350 \mathrm{lb} / \mathrm{hr}$ ), were tested. Both ballasted and unballasted tests were performed at each feed rate. Table 1 summarizes the results of these tests. As an illustration, Figure 4 displays the cooling curve for the case with feed rate of $159 \mathrm{~kg} / \mathrm{hr}$. The addition of fuel to the reactor causes reactor temperature to drop very quickly. Although inflections are not readily apparent in the cooling curve, the rate of cooling is noticeably slowed by the presence of the phase change ballast: cooling time is increased by $102 \%$ (increasing from 5.2 to 10.5 minutes) for the case shown in Figure 4. Lower feed rates allow longer pyrolysis times. However, it does not follow that lower feed rates are desired during pyrolysis. A more detailed analysis is required to appreciate the appropriate feed rate into the reactor during pyrolysis.

Table 1 includes data on the combustion phase (in which both residual char and fresh fuel are burned) and the pyrolysis phase of the gasification cycle. From this information, the average rates at which the reactor burns fresh fuel and pyrolyzes fuel can be calculated. Two important benefits of the ballast can be surmised. First, although

Table 1. Pyrolytic Gasification Cycle Analysis (Combustion Fuel Flow is $45.4 \mathrm{~kg} / \mathrm{hr}$ ).

\begin{tabular}{|c|c|c|c|c|c|c|c|c|}
\hline \multirow{2}{*}{$\begin{array}{c}\text { Feed rate } \\
\text { during } \\
\text { pyrolysis } \\
(\mathrm{kg} / \mathrm{hr})\end{array}$} & \multicolumn{4}{|c|}{ Process time (min) } & \multirow{2}{*}{$\begin{array}{l}\text { Cycles } \\
\text { per } \\
\text { hour }\end{array}$} & \multirow{2}{*}{$\begin{array}{c}\text { Average } \\
\text { combustion } \\
\text { rate* } \\
(\mathrm{kg} / \mathrm{hr})\end{array}$} & \multirow{2}{*}{$\begin{array}{c}\text { Average } \\
\text { pyrolysis } \\
\text { rate* } \\
(\mathrm{kg} / \mathrm{hr})\end{array}$} & \multirow{2}{*}{$\begin{array}{c}\text { Fuel } \\
\text { fraction } \\
\text { pyrolyzed }\end{array}$} \\
\hline & $\begin{array}{l}\text { Char } \\
\text { comb. }\end{array}$ & $\begin{array}{c}\text { Biomass } \\
\text { comb. }\end{array}$ & Pyrolysis & $\begin{array}{c}\text { Cycle } \\
\text { total }\end{array}$ & & & & \\
\hline \multicolumn{9}{|c|}{ Unballasted } \\
\hline 91 & 3.5 & 6.5 & 8.6 & 18.6 & 3.2 & 15.8 & 42.0 & 0.73 \\
\hline 113 & 3.5 & 6.5 & 7.4 & 17.4 & 3.4 & 17.2 & 48.2 & 0.74 \\
\hline 136 & 3.5 & 6.5 & 6.2 & 16.2 & 3.7 & 18.2 & 52.1 & 0.74 \\
\hline 159 & 3.5 & 6.5 & 5.2 & 15.2 & 3.9 & 19.4 & 54.3 & 0.74 \\
\hline \multicolumn{9}{|l|}{ Ballasted } \\
\hline 91 & 3.5 & 9 & 14.3 & 26.8 & 2.2 & 15.3 & 48.4 & 0.76 \\
\hline 113 & 3.5 & 9 & 12.8 & 25.3 & 2.4 & 16.1 & 57.4 & 0.78 \\
\hline 136 & 3.5 & 9 & 12.5 & 11.5 & 2.5 & 17.0 & 65.2 & 0.79 \\
\hline 159 & 3.5 & 9 & 12.5 & 10.5 & 2.6 & 17.8 & 72.4 & 0.80 \\
\hline
\end{tabular}

* Averaged over cycle. Combustion rate based on burning fresh biomass. 


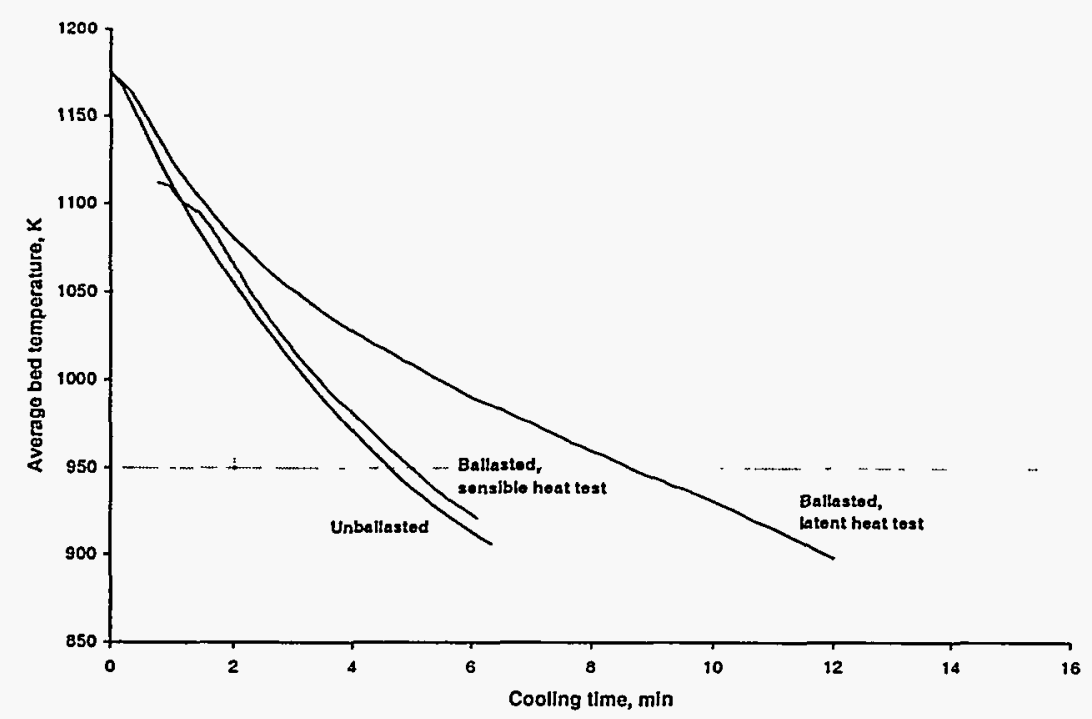

Figure 4. Reactor Cooling Curve for Pyrolysis of Fuel (159 kg/hr)

pyrolysis time decreases as fuel feed rate increases, the total amount of fuel pyrolyzed for the cycle increases; that is, the time-averaged pyrolysis rate increases. A similar effect is observed with the unballasted gasifier, but the effect is much less dramatic than for the ballasted gasifier and shows diminishing returns as fuel feed rate increases.

Secondly, the ballast yields more efficient conversion of biomass to product gas. At the highest throughputs for the ballasted gasifier, approximately $20 \%$ of the fuel is combusted to support pyrolysis of the remaining $80 \%$. In comparison, at comparable operating conditions, the unballasted gasifier combusts $26 \%$ of the fuel to support pyrolysis of the remaining $74 \%$.

\section{Gas analysis}

Thirteen gas samples were taken over a range of steam-fuel ratios and temperatures. Both the GC and the FT-IR were used to quantify the gas mixtures. The GC was able to quantify $\mathrm{H}_{2}, \mathrm{~N}_{2}, \mathrm{O}_{2}, \mathrm{CO}, \mathrm{CH}_{4}$, and $\mathrm{CO}_{2}$. The FT-IR was able to quantify $\mathrm{CO}, \mathrm{CH}_{4}, \mathrm{CO}_{2}$, and $\mathrm{C}_{2} \mathrm{H}_{4}$. The FT-IR also detected the presence of significant amounts of $\mathrm{C}_{2} \mathrm{H}_{2}$ and $\mathrm{C}_{2} \mathrm{H}_{6}$, but these constituents were not quantified accurately; they are believed to total $0.5-$ $2 \%$ of the total gas volume. Table 2 shows the range of values and the average gas composition measured. Nitrogen and oxygen were removed from the analysis on the assumption that the purge gas could be replaced with recycled flue gas or steam. The calculated higher heating value ranges from 14.2 to $16.6 \mathrm{MJ} / \mathrm{Nm}^{3}$ (382-445 Btu/scf). These values are significantly higher than for air-blown gasification and are similar to values reported for other indirectly-heated gasifiers. 
Table 2. Dry Producer Gas Analysis.

\begin{tabular}{lccccccccc}
\hline & \multicolumn{1}{c}{ Gas constituents $\left(\mathrm{N}_{2}, \mathrm{O}_{2}\right.$ free $)$} & \multicolumn{3}{c}{ Heating value } \\
& $\mathrm{H}_{2}$ & $\mathrm{CO}$ & $\mathrm{CH}_{4}$ & $\mathrm{CO}_{2}$ & $\mathrm{C}_{2} \mathrm{H}_{2}$ & $\mathrm{C}_{2} \mathrm{H}_{4}$ & $\mathrm{C}_{2} \mathrm{H}_{6}$ & $\mathrm{~kJ} / \mathrm{m}^{3}$ & $\mathrm{Btu} / \mathrm{scf}$ \\
\hline Average & 26.2 & 39.0 & 10.3 & 18.3 & $0.5^{\mathrm{a}}$ & 5.2 & $0.5^{\mathrm{a}}$ & 15400 & 415 \\
Range & $20.5-$ & $28.9-$ & $7.9-$ & $14.3-$ & $0.5^{\mathrm{a}}$ & $4.76-$ & $0.5^{\mathrm{a}}$ & $14200-$ & $382-445$ \\
& 35.9 & 46.8 & 11.5 & 25.0 & & 5.96 & & 16600 & \\
\hline
\end{tabular}

(a) Estimates

\section{CONCLUSIONS}

Pyrolytic gasification experiments with the latent heat ballast were successful. At the highest throughput, reactor cooling time, an indicator of the thermal behavior of the system, increased $102 \%$ over the unballasted reactor. Additionally, the fuel fraction pyrolyzed to produce useful gas is increased from $74 \%$ to $80 \%$. Not only can the ballasted reactor process more fuel than the unballasted reactor, it can process it more efficiently. The gas quality produced by the pyrolytic gasifier was substantially higher than that produced during air-blown gasification. Dry gas higher heating values ranged from 14.2 to $16.6 \mathrm{~kJ} / \mathrm{m}^{3}$ (382-445 Btu/scf).

\section{ACKNOWLEDGMENTS}

The authors would like to thank Mr. and Mrs. William Catron for their generous support of one of the authors (R. P.) during his graduate studies.

\section{REFERENCES}

1. Battelle Columbus Laboratory, "Process Scale-Up Data Summary," Report Prepared for U.S. DOE Richland Operations Office, Nov. 27, 1985.

2. Dallas, I., McLellan, R.J., Scanlon, K.E., and Smith, D.H., "The Gasification of Wood Using the Oxygen Donor Process, " in Advanced Gasification, A.A.C.M. Beenackers and W. Van Swaay, Eds., Reidel Publishing, Boston, 1986, pp. 115-172.

3. Mansour, M., Durai-Swamy, K., \& Voelker, G. "MTCI/ThermoChem Steam Reforming Process for Biomass." In Proceedings of the Second Biomass Conference of the Americas. Golden, CO: National Renewable Energy Laboratory, 1995.

4. Stobbe, S. Oatley, J., and Brown, R. C., "Indirectly-heated biomass gasification using latent-heat ballasting of a fluidized reactor," $31^{\text {st }}$ Intersociety Energy Conversion Conference, Washington, D.C., August 11-16, 1996. 